Revista de Biología Marina y Oceanografía

Vol. 50, №3: 583-586, diciembre 2015

DOI: 10.4067/S0718-19572015000400015

\title{
Research Note \\ First record of the dinoflagellate Oxytoxum caudatum (Peridiniales: Oxytoxaceae) in the Gulf of California
}

\author{
Primer registro del dinoflagelado Oxytoxum caudatum (Peridiniales: \\ Oxytoxaceae) en el Golfo de California \\ Ismael Gárate-Lizárraga ${ }^{1}$ and Rogelio González-Armas ${ }^{1}$
}

\begin{abstract}
Instituto Politécnico Nacional, Centro Interdisciplinario de Ciencias Marinas, Departamento de Plancton y Ecología Marina, Apartado postal 592, La Paz, Baja California Sur, 23000, México. igarate@ipn.mx

Abstract.- As part of a continuing microalgae monitoring program, phytoplankton samples were collected from 19 August 2014 to 25 February 2015 at a fixed sampling site in the southern part of the Bahía de La Paz, Mexico. The armored dinoflagellate Oxytoxum caudatum was observed mainly in net samples of phytoplankton. Study of live specimens did not show great variation in cell size or shape. Cells were $24-38 \mu \mathrm{m}$ long and 12-16 $\mu \mathrm{m}$ wide $(n=30)$. This is the first record of 0 . caudatum in the Gulf of California.
\end{abstract}

Key words: Dinoflagellates, Oxytoxum caudatum, Bahía de La Paz, Gulf of California

\section{INTRODUCTION}

Dinoflagellates are one of the most important components in marine phytoplankton. These plankton are unicellular protists that exhibit great diversity of both shape and size. Roughly, half of the species in the group are photosynthetic (Gaines \& Elbrächter 1987); the other half is exclusively heterotrophic. Dinoflagellates are described as armored or unarmored, according to the type of cell covering (theca or amphiesma), which always consists of several layers of membranes. The armored group has a number of cellulosic plates, and the unarmored group lacks plates (Vlamis \& Katibou 2014). About 605, principally freeliving, dinoflagellate species and infraspecific taxa from 91 genera have been reported along the Pacific coast of Mexico (Okolodkov \& Gárate-Lizárraga 2006). However, this list has expanded as new dinoflagellate records are published (Gárate-Lizárraga 2008, 2009, 2013, 2014; GárateLizárraga et al. 2009, 2014; Esqueda-Lara \& HernándezBecerril 2010, Meave del Castillo et al. 2012, Maciel-Baltazar \& Hernandez-Becerril 2013). The leading genera are Protoperidinium (111 species), Ceratium (63) Dinophysis (41), Gonyaulax (25) and Oxytoxum (22). The most obvious characteristic feature of members of the latter is the position of the girdle, which normally divides the cell into a small epitheca and a larger hypotheca (Dodge \& Sanders 1985). Cells of the genus Oxytoxum are characterized as elongated with pointed apices that are clavate to fusiform. This report describes the first record of Oxytoxum caudatum in the Gulf of California.

\section{MATERIALS AND METHODS}

As part of an ongoing toxic and noxious microalgae monitoring program, phytoplankton bottle samples were collected monthly at one fixed sampling station in the

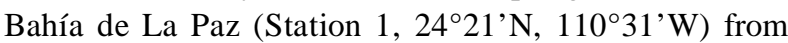
August 2014 through February 2015. The sampling station is located above the shallow basin at the southernmost end of the bay (see Gárate-Lizárraga 2014). Phytoplankton samples were collected in plastic flasks, fixed with Lugol's solution, and later preserved with $4 \%$ formalin. Surface and vertical tows at $15 \mathrm{~m}$ depth were made with a $20 \mu \mathrm{m}$ mesh phytoplankton net. Sea surface temperature was measured with a bucket thermometer (Kahlsico International, El Cajon, CA, USA). Examination and identification of $O$. caudatum was done under a Carl Zeiss ${ }^{\circledR}$ phase-contrast microscope. An Olympus ${ }^{\circledR} \mathrm{CH} 2$ compound microscope was used to measure the cells and a digital Konus ${ }^{\circledR}$ camera $(8.1 \mathrm{MP})$ recorded the images.

\section{RESULTS AND DISCUSSION}

In this work 58 specimens of $O$. caudatum were identified and measured from 13 phytoplankton net samples. $O$. caudatum was not found in bottle samples, therefore, no quantitative data are shown. Temperatures recorded at the same time as the collections ranged from 22 to $31^{\circ} \mathrm{C}$ (Table 1). 
Table 1. Sampling dates, specimens of Oxytoxum caudata, and temperature in 13 samplings from the southern Bahía de La Paz, August 2014 through February 2015 / Fecha de los muestreos, especímenes de Oxytoxum caudata y temperatura en 13 muestreos realizados al sur de la Bahía de La Paz, en agosto 2014 hasta febrero 2015

\begin{tabular}{ccc}
\hline $\begin{array}{c}\text { Sampling } \\
\text { dates }\end{array}$ & $\begin{array}{c}\text { Specimens of } O . \\
\text { caudata }\end{array}$ & $\begin{array}{c}\text { Temperature } \\
\left({ }^{\circ} \mathrm{C}\right)\end{array}$ \\
\hline $19 / 08 / 2014$ & 3 & 31.0 \\
$20 / 08 / 2014$ & 4 & 31.0 \\
$29 / 09 / 2014$ & 5 & 29.5 \\
$30 / 09 / 2014$ & 7 & 29.5 \\
$22 / 10 / 2014$ & 5 & 28.0 \\
$23 / 10 / 2014$ & 4 & 27.5 \\
$19 / 11 / 2014$ & 4 & 26.0 \\
$20 / 11 / 2014$ & 5 & 26.0 \\
$16 / 12 / 2014$ & 3 & 24.5 \\
$17 / 12 / 2014$ & 5 & 24.0 \\
$15 / 01 / 2015$ & 3 & 22.0 \\
$16 / 01 / 2015$ & 5 & 22.0 \\
$25 / 02 / 2015$ & 5 & 23.0 \\
\hline
\end{tabular}
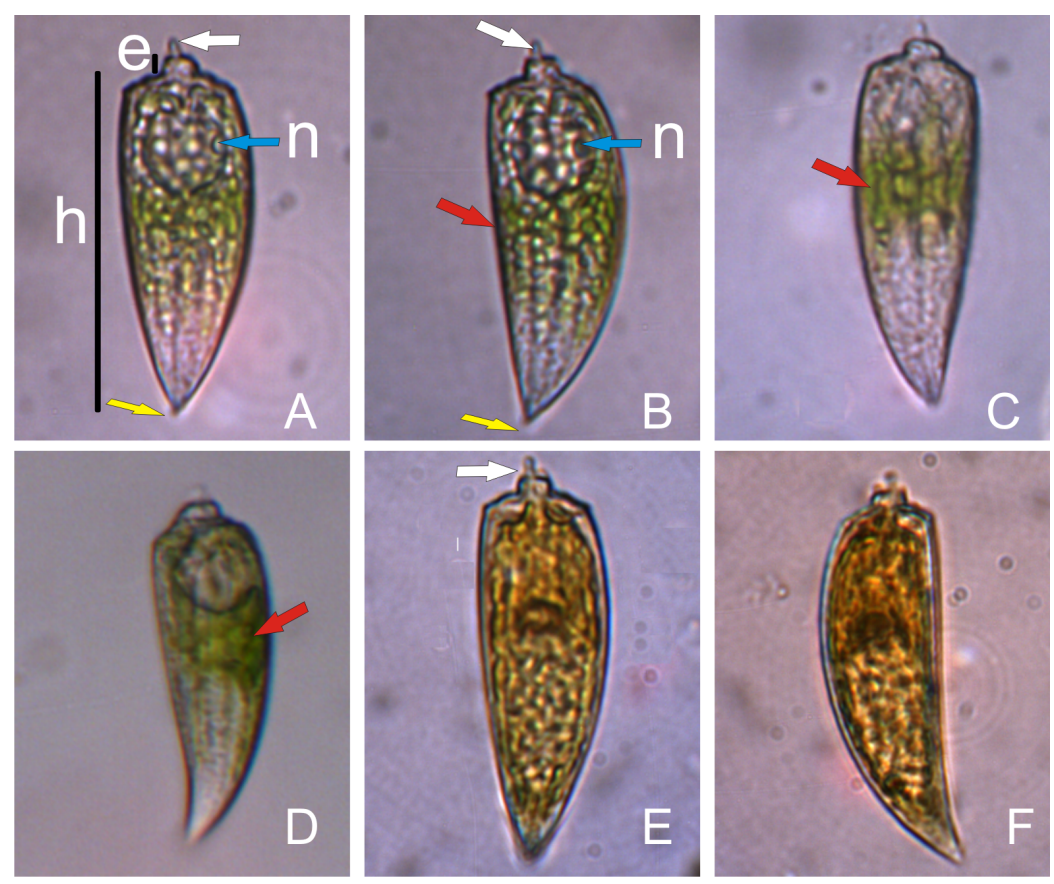

\section{OxYTOXUM CAUDATUM SCHILLER, 1937 (Figs. 1A-F)}

Synonym (s): O. nanum Halldal, 1953, p. 56, fig. 20

References: Schiller, 1937, p. 454, fig. 504; Wood, 1963, p. 44, fig. 160; Dodge \& Saunders, 1985, p. 113-114, figs. 3134; Ochoa \& Gómez, 1997, p. 56, fig. 2; Gómez et al., 2008, p. 28 , figs. $31-34$.

Dimensions: Cells are 24-38 $\mu \mathrm{m}$ long $(30.10 \pm 4.23)$ and 12 $16 \mu \mathrm{m}$ wide $(14.70 \pm 1.21)$.

Brief description: Our specimens fit the description of $O$. caudatum in terms of cell shape and size (see references above). Cells have a sub-orbicular body with obtusely angled apex and subacute, slightly spined antapex. Cells have straight or slightly convex sides. Epitheca is low and conical and looks like a small button-like structure, with small apical spine (Figs. 1A-F); hypotheca is wider than epitheca, tapering to acute antapex. The contour of the hypotheca of $O$. caudatum is slightly shouldered. The theca is extremely fragile, has a smooth surface, and no plates have been seen, as yet (Dodge \& Saunders 1985). Specimens of $O$. caudatum seem to have an elongated plate-shaped chloroplast (Figs. 1A-D). The nucleus is in the upper part of the hypocone (Figs. 1A-B).

Figure 1. A-F) Light microphotographs of several specimens of Oxytoxum caudatum from the Bahía de La Paz. (A) Specimen of 0 . caudatum showing the epitheca (e), the hypotheca ( $h$ ) and the nucleus $(n)$ is indicated with a blue arrow; White arrows indicate the apical spine (A, B and E); Yellow arrows indicate the antapical spine (A and $B$ ); Orange arrows indicate the chloroplast (B, C and D); Specimens in lateral view (D and F); Cells of Oxytoxum caudatum fixed in Lugol's solution ( $E$ and F) / A-F) Microfotografías de luz de algunos especímenes de Oxytoxum caudatum de Bahía de La Paz. (A) Espécimen de 0 . caudatum mostrando la epiteca (e), la hipoteca (h) y el núcleo $(n)$ es señalado con una flecha azul; Las flechas blancas indican la espina apical (A, B y E); Las flecha amarillas indican la espina antapical (A y B); Las flechas naranjas indican el cloroplasto ( $B, C$ y $D)$; Especímenes en vista lateral ( $D$ y F); Células de Oxytoxum caudatum fijadas con solución de Lugol (EyF) 
$O$. caudatum is closely related to $O$. curvatum (Kofoid) Kofoid 1911. Major differences between them are: Unlike the former, $O$. curvatum has a ventral side, markedly concave in lateral view (see Schiller 1937, Gómez et al. 2008) and without a central pimple at the apex, characteristic of $O$. caudatum (see Dodge \& Saunders, 1985: p. 112); the small apical spine is clearly visible in our specimens and absent in $O$. curvatum. No antapical spine is reported in the original description of $O$. curvatum (Kofoid 1907, Kofoid \& Michener 1911). The nucleus is located in the upper part of the hypocone of $O$. caudatum and in the lower part of the hypocone in O. curvatum. All of these morphological differences between these species led us to identify our specimens as $O$. caudatum.

Regional distribution: Recorded twice along the Pacific coast of Mexico; first at El Faro, Michoacán (Okolodkov \& Gárate-Lizárraga 2006), and recently in Bahía de Acapulco (Meave del Castillo et al. 2012). The distribution of $O$. caudatum is now extended with this finding in the Gulf of California. Records of this species occur only in coastal waters from the Pacific coast of Mexico. $O$. curvatum was reported once in Puerto el Sauzal in the northern part of Baja California (Hernández-Becerril 1986), but not in the Gulf of California.

General distribution: This species has been recorded in the Adriatic Sea (Schiller 1937), in Galway Bay (Ireland) (Dodge \& Saunders 1985), the Mediterranean Sea (Vilièiæ et al. 2002, Gómez 2003), the Caribbean Sea (Wood 1968), the Gulf of Mexico (Licea et al. 2004), along the Eastern Tropical coast of Australia (Wood 1963), the Japan Sea (Konovalova 2000), in the North Pacific Gyre (Venrick 1982), equatorial southeast Pacific (Iriarte \& Fryxell 1995, Liu et al. 1996, Ochoa \& Gómez 1997), and in the open southeastern Pacific Ocean (Gómez et al. 2008). Okolodkov et al. (2007) consider $O$. caudatum as nonindigenous plankton along the Mexican coast or an introduced species for other areas. The presence of this species in Bahía de La Paz supports this hypothesis because phytoplankton studies have been performed since the late 1970 s and was not previously recorded (Gilmartin \& Revelante 1978, Signoret \& Santoyo 1980). The presence of $O$. caudatum for seven months indicates that hydrographic conditions in the Bahía de La Paz were favorable for this species.

\section{ACKNOWLedgments}

The projects were funded by grants from the Instituto Politécnico Nacional (SIP-20141181, SIP-20141095, SIP-
20150500 and 20150537). We also thank the anonymous reviewers who provided useful comments and suggestions, which improved the manuscript. The authors are COFAA and EDI fellows.

\section{LITERATURE CITED}

Dodge JD \& RD Saunders. 1985. A partial revision of the genus Oxytoxum (Dinophyceae) with the aid of scanning electron microscopy. Botanica Marina 28: 99-122.

Esqueda-Lara K \& DU Hernández-Becerril. 2010. Dinoflagelados microplanctónicos marinos del Pacífico central de México (Isla Isabel, Nayarit y costas de Jalisco y Colima), 206 pp. Instituto de Ciencias del Mar y Limnología, Universidad Nacional Autónoma de México, Ciudad de México.

Gaines G \& M Elbrächter. 1987. Heterotrophic nutrition. In: Taylor FJR (ed). The biology of dinoflagellates. Botanical Monographs 21:224-226. Blackwell Scientific Publications, Oxford.

Gárate-Lizárraga I. 2008. Nuevos registros de dinoflagelados planctónicos para el Golfo de Tehuantepec, México. CICIMAR Oceánides 23: 55-65.

Gárate-Lizárraga I. 2009. First record of Ceratium dens (Dinophyceae) in the Gulf of California. CICIMAR Oceánides 24: 167-173.

Gárate-Lizárraga I. 2013. Bloom of Cochlodinium polykrikoides (Dinophyceae: Gymnodiniales) in Bahía de La Paz, Gulf of California. Marine Pollution Bulletin 67: 217-222.

Gárate-Lizárraga I. 2014. Unarmored dinoflagellates present during a bloom of Ceratoperidinium falcatum in Bahía de La Paz, Gulf of California. Revista de Biología Marina y Oceanografía 43: 577-587.

Gárate-Lizárraga I, CJ Band-Schmidt, F Aguirre-Bahena \& T Grayeb-del Álamo. 2009. A multi-species microalgae bloom in Bahía de La Paz, Gulf of California, Mexico (June 2008). CICIMAR Oceánides 24: 1-15.

Gárate-Lizárraga I, MS Muñetón-Gómez, B Pérez-Cruz \& JA Díaz-Ortíz. 2014. Bloom of Gonyaulax spinifera (Dinophyceae: Gonyaulacales) in Ensenada de La Paz lagoon, Gulf of California. CICIMAR Oceánides 29: 1118.

Gilmartin M \& N Revelante. 1978. The phytoplankton characteristics of the barrier island lagoons of the Gulf of California. Estuarine and Coastal Marine Science 7: 29-47.

Gómez F. 2003. Checklist of Mediterranean free-living dinoflagellates. Botanica Marina 46: 215-242.

Gómez F, H Claustre \& S Souissi. 2008. Rarely reported dinoflagellates of the genera Ceratium, Gloeodinium, Histioneis, Oxytoxum and Prorocentrum (Dinophyceae) from the open southeast Pacific Ocean. Revista de Biología Marina y Oceanografía 43: 25-40. 
Hernández-Becerril DU. 1986. Un estudio sobre fitoplancton en el Puerto de El Sauzal, Baja California, México. Revista Latino-Americana de Microbiología 28: 167-175.

Iriarte JL \& GA Fryxell. 1995. Microplankton at the equatorial Pacific $\left(140^{\circ} \mathrm{W}\right)$ during the JGOFS EqPac Time Series studies: March to April and October 1992. Deep Sea Research II 42: 559-583.

Kofoid CA. 1907. New species of dinoflagellates. Reports on the scientific results of the expedition to the Eastern Tropical Pacific. Bulletin of the Museum of Comparative Zoology at Harvard College 50: 161-207.

Kofoid CA \& JR Michener. 1911. New genera and species of dinoflagellates. Bulletin of the Museum of Comparative Zoology at Harvard College 54(7): 1-265.

Konovalova GV. 2000. Analysis of the dinophyte (Dinophyceae) flora of the Russian Far East and adjacent waters of the Pacific. Asian Marine Biology 17: 1-14.

Licea S, ME Zamudio, R Luna \& J Soto. 2004. Free-living dinoflagellates in the southern Gulf of Mexico: report of data (1979-2002). Phycological Research 52: 419-428.

Liu D, AG Fryxell \& I Kaczmarska. 1996. El Niño (1992) in the Equatorial Pacific: Low biomass with a few dominating species in micro-phytoplankton. Journal of Plankton Research 18: 1167-1184.

Maciel-Baltazar E \& DU Hernandez-Becerril. 2013. Especies de dinoflagelados atecados (Dinophyta) de la costa de Chiapas, sur del Pacífico mexicano. Revista de Biología Marina y Oceanografía 48: 245-259.

Meave del Castillo ME, ME Zamudio-Resendiz \& M Castillo-Rivera. 2012. Riqueza fitoplanctónica de la Bahía de Acapulco y zona costera aledaña, Guerrero, México. Acta Botanica Mexicana 100: 405-487.

Ochoa N \& O Gómez. 1997. Dinoflagellatae of Peruvian Sea as indicators of water masses during 1982 to 1985 . Boletín Instituto del Mar de Perú 162: 1-60.
Okolodkov YB \& I Gárate-Lizárraga. 2006. An annotated checklist of dinoflagellates (Dinophyceae) from the Mexican Pacific. Acta Botanica Mexicana 74: 1-154.

Okolodkov YB, R Bastida-Zavala, AL Ibáñez, JW Chapman, E Suárez-Morales, F Pedroche \& FJ GutiérrezMendieta. 2007. Especies acuáticas no indígenas en México. Ciencia y Mar 9: 29-67.

Signoret M \& H Santoyo. 1980. Aspectos ecológicos del plancton de la Bahía de La Paz, Baja California Sur. Anales del Instituto de Ciencias del Mar y Limnología, Universidad Nacional Autónoma de México 7: 217-248.

Schiller J. 1937. Dinoflagellate (Peridineae). In: Rabenhorst L (ed). Kryptogamen-Flora of Deutschland, Österreich und der Schweiz 2: 1-590. Akademische Verlagsgesellschaft, Leipzig.

Venrick EL. 1982. Phytoplankton in an oligotrophic ocean: observations and questions. Ecological Monographs 52: 129-154.

Vilièiæ D, I Marasoviæ \& D Miokoviæ. 2002. Checklist of phytoplankton in the eastern Adriatic Sea. Acta Botanica Croatica 61: 57-91.

Vlamis A \& P Katikou. 2014. Ecobiology and geographical distribution of potentially toxic marine dinoflagellates. In: Botana LM (ed). Seafood and freshwater toxins pharmacology, physiology, and detection, pp. 569-626. CRC Press, Boca Raton.

Wood EJF. 1963. Dinoflagellates in the Australian region. II. Recent collections. Technical Papers of the Division of Fisheries Australia 14: 1-55.

Wood EJF. 1968. Dinoflagellates of the Caribbean Sea and adjacent areas, 142 pp. University of Miami Press, Coral Gables. 